九州大学学術情報リポジトリ

Kyushu University Institutional Repository

\title{
NEW NAMES OF PALAEORHIZA
}

Hirashima, Yoshihiro

https://doi.org/10.5109/2440

出版情報: ESAKIA. 20，pp.129-129，1983-12-15. Entomological Laboratory，Faculty of Agriculture, Kyushu University バージョン :

権利関係 : 


\title{
NEW NAMES OF PALAEORHIZA
}

\author{
Yoshihiro Hirashima
}

The following new names of Palaeorhiza are proposed.

\section{Palaeorhiza (Cnemidorhiza) persimilis Hirashima, new name}

The new name is proposed for Palaeorhiza (Cnemidorhiza) simulans Hirashima, 1981, Esakia, (17) : 14, nec Palaeorhiza (Paraheterorhiza) simulans Hirashima, 1980, J. Fac. Agr., Kyushu Univ., 25: 107.

2. Palaeorhiza (Heterorhiza) cockerelli Hirashima et Lieftinck, new name

The new name is proposed for Palaeorhiza (Heterorhiza) amabilis Hirashima et Lieftinck, 1982, Esakia, (19) : L3, nec Palaeorhiza (Cheesmania) amabilis Hirashima, 1981, Kontyû, 49: 30. 